\title{
Analysis of financial education in children of fifth grade of elementary in urban schools of the city of Navojoa, Sonora
}

\section{Análisis de educación financiera en niños de quinto grado de primaria en escuelas urbanas de la ciudad de Navojoa, Sonora}

\author{
MURILLO-FÉLIX, Cecilia Aurora†*, ACOSTA-MELLADO, Erika Ivett, GALVAN-CORRAL, Alberto \\ and QUIROZ-CAMPAS, Celia Yaneth
}

Instituto Tecnológico de Sonora, Calle 5 de Febrero 818, Centro, Urb. No. 1, 85000 Cd Obregón, Son.

ID $1^{\text {st }}$ Author: Cecilia Aurora, Murillo-Félix / ORC ID: 0000-0002-2214-9880, CVU CONACYT ID: 971874

ID $1^{\text {st }}$ Coauthor: Erika Ivett, Acosta-Mellado / ORC ID: 0000-0003-3526-8923, CVU CONACYT ID: 281305

ID $2^{\text {nd }}$ Coauthor: Albert, Galvan-Corral / CVU CONACYT ID: 93702

ID $3^{\text {rd }}$ Coauthor: Celia Yaneth, Quiroz-Campas / ORC ID: 0000-0002-6068-1552, CVU CONACYT ID: 281305

\begin{abstract}
The present research shows a diagnosis whose objective was to know the level of financial education that the fifth grade children of the city of Navojoa, Sonora, have to make a didactic proposal. The research was exploratory, descriptive and transversal, using the case study. A questionnaire was applied to 1,862 fifth grade children in urban schools in Navojoa city, Sonora. The questionnaire included seven variables with 35 questions using the Multiple Response Model. The results indicated, according to the scale used, that respondents possess acceptable knowledge in financial education. ANOVA confirmed significant differences in some variables taking into consideration aspects such as the type of school, school grade, sex, age and parental education level.
\end{abstract}

Economía, Educación Financiera, Diagnostico

\begin{abstract}
Resumen
La presente investigación muestra un diagnostico cuyo objetivo fue conocer el nivel de Educación Financiera que tienen los niños de quinto grado de primaria de la ciudad de Navojoa, Sonora, para posteriormente realizar una propuesta didáctica. La investigación fue exploratoria, descriptiva y transversal, utilizando el estudio de casos. Se aplicó un cuestionario a 1,862 niños de quinto grado, en escuelas urbanas de la ciudad de Navojoa, Sonora. El cuestionario incluyó siete variables con 35 preguntas utilizando el Modelo de Respuesta Múltiple. Los resultados indicaron, según la escala utilizada, que los encuestados poseen conocimientos aceptables en materia de Educación Financiera. El ANOVA confirmó diferencias significativas en algunas variables tomando en cuenta aspectos como el tipo de escuela, el grado escolar, el sexo, la edad de los encuestados, y la escolaridad de los padres.
\end{abstract}

Economy, Financial Education, Diagnosis

Citation: MURILLO-FÉLIX, Cecilia Aurora, ACOSTA-MELLADO, Erika Ivett, GALVAN-CORRAL, Alberto and QUIROZCAMPAS, Celia Yaneth. Analysis of financial education in children of fifth grade of elementary in urban schools of the city of Navojoa, Sonora. Journal Schools of economic Thought and Methology. 2019. 3-5: 24-33.

\footnotetext{
* Correspondence to Author (email: cecilia.murillo@itson.edu.mx)

$\dagger$ Researcher contributing as first author.
} 


\section{Introduction}

Throughout history, the human being has been adapting according to his needs, one of the most important has been knowledge, because thanks to this he can survive. According to The National Savings Bank and Financial Services, National Credit Society (2005), financial education is a process of development of skills and attitudes that, through the assimilation of understandable information and basic instruments of resource management and planning, allows to individuals: a) make personal and social decisions of an economic nature in their daily lives, and b) manage financial products and services to improve their quality of life under certain conditions.

A study prepared by UNICEF (2013), revealed the concept of Social and Financial Education for Children (ESFI) providing guidelines for ESFI in child-friendly schools. It was aimed at developing the sense of control that children have over their own lives, as well as improving and strengthening their self-esteem, also encouraging them to participate in issues that affect them and their communities, as socially and economically empowered citizens.

González (2015), conducted a study to university students in San Luis Potosí, which aimed to develop proposals to increase knowledge about financial culture, said author, began by raising awareness of basic financial concepts, explaining what is the process in which The necessary knowledge, skills and abilities are obtained to favor more accurate decision-making regarding the administration of its economy. One of the main goals that the financial culture seeks is to be mostly informed and trained to be able to use financial products and services with greater awareness. In the results obtained, it was found that many of the participating students showed low savings culture, since their income is insufficient, they also showed distrust of bank loans and credit card management, so it was concluded that there is Limited financial culture.

In the same sense, Aguilar and Ortiz Veintimilla (2013), developed an investigation which is supported by the diagnosis that was applied through the "Survey to determine the level of education and financial culture", (ENFIN) that counts with four sections:
1. knowledge and understanding, 2. financial planning, 3. financial control, 4. products and services; where the results showed that the levels of education and financial culture of the professionals in training of the degree of Banking and Finance of the UTPL were located between low and medium. The main objective of the research was to implement a program of education and financial culture for students, because, through an executed diagnosis, it was determined that the level with which they had financial culture was at a low-medium average. According to this, a plan was formed in order to raise awareness and educate students as well as people in general to learn to have greater control of their personal finances.

Sucasaca (2016) conducted an investigation that aimed to diagnose the determinants of Financial Education in adults in the San Santiago urbanization of the city of Juliaca. For this, a correlational, explanatory and cross-sectional study was carried out. Where the Tobit econometric model was used to estimate the incidence of saving capacity (CAPAHO), buying habits (HC) and the knowledge and use of financial products (CPFIN) in financial education (EF). Three econometric models were evaluated, where the results of model 1 better and correctly predict the incidence of the variables: CAPAHO, $\mathrm{HC}$, and CPFIN regarding the financial education of adults, at the same time, these revealed a direct relationship with Financial Education, showing individual significance (t-student), and an equally significant R2. Therefore, greater awareness of the adult population was advised for the management of savings, purchasing habits and financial products.

Finally, it is known that Mexico currently has a low financial culture due to various factors, the most alarming is the level of illiteracy of the population since around 6 million adults do not know how to read or write, this occurs more in the indigenous and communities rural, obviously these people do not have financial education, so if you want to raise knowledge, you have to work with a lot of effort and dedication (Pérez, 2010). 


\section{Problem Statement}

Dominguez (2017) states that according to the latest National Survey of Financial Inclusion (ENIF) jointly carried out by the National Banking and Securities Commission (CNBV) and the National Institute of Statistics and Geography (Inegi), Mexico shows an increase in some activities financials that help Mexicans to have proper management of their money.

Financial education is an issue that has caused controversy over the years, in Mexico only $32 \%$ of adults have this type of education, while in countries like Norway and Sweden they have approximately $71 \%$. This is because people do not know how to save, they do not distribute or plan their expenses well, they are afraid of credit cards, on several occasions they acquire loans without knowing the interest they are going to pay or they do not understand and simply decide to trust some bank advisor (Dominguez, 2017).

At present, having a good level of financial education is substantial, being informed, being able to help and setting an example to other people will give way to economic benefit. As mentioned, Mexico is at a very low level, therefore the following research question arises:

What is the level of financial education that fifth grade elementary students have in elementary schools in the city of Navojoa, Sonora?

\section{Objective}

Identify the level of financial education that fifth grade students have in the schools of the city of Navojoa, Sonora, through the application of an instrument, to generate strategies to raise knowledge based on financial education.

\section{Specific goal.}

Describe in which variables of financial education the students of fifth grade have a greater mastery of the concepts and what are the variables in which they show a lower domain, which will allow the development of didactic strategies in the teaching of subjects of financial education.

\section{Justification}

Financial education is a process in which attitudes, skills and abilities are acquired through the compression of planning and resource management, which gives way to better economic decision making and efficient use of financial products and services. everyday life, in order to improve people's quality of life. Nowadays Mexico has very low rates in this area, to be able to provide basic knowledge, to elementary students will help them to strengthen themselves in the financial environment and to create and encourage others to have this type of culture. That students have knowledge about financial education will help them understand the value of money, what is savings and therefore spending, which are basic concepts to understand how finance works, as well as knowing a little about planning, which It has an extremely important role in this.

\section{Theoretical Foundation}

Financial education is defined as the process by which consumers and financial investors increase their understanding of financial products, concepts and risks, and that through information, instruction and / or objective advice, develop skills and confidence to be more careful and responsible for financial risks and opportunities, to make informed decisions, to know where to go for assistance and to be able to take any effective action to reform their economic well-being (OECD, 2005).

Financial education is defined as the process by which consumers and financial investors increase their understanding of financial products, concepts and risks, and that through information, instruction and / or objective advice, develop skills and confidence to be more careful and responsible for financial risks and opportunities, to make informed decisions, to know where to go for assistance and to be able to take any effective action to reform their economic well-being (OECD, 2005).

Zunzunegui (2006) states that financial education improves market understanding and financial products by consumers; This can be achieved through information on financial products, learning about the functioning of markets, and even independent advice. 
Thus, a consumer who has sufficient knowledge, will know where to get help, in order to improve the profitability of their investments, so that investors can be more aware of the risks and opportunities that may arise with respect to your decisions

\section{Importance of financial education}

On the other hand, as argued by the Association of Banks of Mexico (2008), financial education is very important because:

- It allows people to understand financial concepts and products.

- Develop skills and build confidence.

- Allows you to be aware of the opportunities and risks of your decisions.

- People know where to go if they have any questions.

- Promotes decision making that improves your financial well-being.

- It helps to reduce inequality.

Currently this type of education is much more important than in ancient times, since people are interested and give more weight, so the Association of Banks of Mexico (2008) highlights that it favors:

- Rapid development of financial markets.

- The complexity of financial products.

- Greater number of financial institutions.

- Superior offer of financial products, social, political and demographic changes (increase in life prospects).

- Adjustments in pension schemes.

- Persistence of low levels of education.

From the position of The National Commission of the Retirement Savings System (2015) the importance of financial and pension education has been documented through various studies that prove that:
- The more financial education, the more savings.

- The more financial education, the better investment decisions.

- The more financial education, the more rational use of credit.

- A higher financial education, lower levels of indebtedness.

- The more financial education, the better pensions.

- The higher the financial education, the higher standard of living.

\section{Financial habits}

From the point of view of Xirau (2018), there are 3 financial habits that all people must have, cost reduction, for this a budget must be made and given priority to certain cash disbursements; debt reduction, to have less money outflows and thereby increase savings; and invest to grow money. According to ASOBANCARIA (2017), habits are the knowledge, actions and attitudes that are acquired and performed naturally and spontaneously so that they can benefit daily life. Also, personal finances are based on habits, one of the practices that can improve them are:

- Budget, to keep track of income and expenses.

- Save, allocate a portion of the income to cover a future event.

- Get out of debt.

- Invest, to obtain more performance as long as you are willing to take risks.

- Plan, determine upcoming expenses and income.

- Pay early, to have a better credit history.

- Protect, to minimize economic impacts.

- Train in financial education, to understand the financial field. 


\section{Saving}

Given the above conditions, an important concept in financial education is savings, several authors (Saving Trust, 2006; Martín, 2008; Andersen, 1999) specify how the portion of the disposable income of a subject that is not spent on basically goods and / or services, saving is the percentage of income that is not destined for expenditure and that is reserved for future needs that will come to be presented, through various financial mechanisms, is the result of the activity of saving a part of current consumption to designate it for future consumption. Positive difference between income and expenses. Saving is to protect a fraction of the income and keep it for later use or for the formation of capital. The Bank of Mexico states that saving is the excess monetary amount of people and institutions of their expenses. It is the income not consumed, that is to say the positive inequality between income and consumption that is derived from the confrontation between the income and expenses of an entity.

Taking into account the Royal Spanish Academy defines savings as a reserve of a part of the common income, fundamentally is to save money as anticipation for future needs, is to avoid spending or higher consumption.

\section{Importance of saving}

As mentioned earlier, saving is extremely important both for families and institutions, so Huidobro (1995) emphasizes that saving plays a fundamental role in the development of countries, since it makes up the origin of resources for the financing of the investment and with it to be able to contribute to the generation of projects that promote economic and social development. Families save money for the acquisition of a tangible asset or for their retirement, on the other hand, companies gather utilities to build new factories and governments accumulate infrastructure and pension assets.

According to Ortiz (2015), the importance of saving is in the availability, since it allows to settle the commitments that are acquired over time. Currently, society lives in a capitalist world, where the system proposes the management of resources for the exchange of goods and services that facilitate people's lives.
If this habit is encouraged from an early age, saving behavior will be achieved and therefore it would be easy to maintain it.

Ortiz (2017) declares that the importance of saving lies in having availability, that is, having money available to solve different situations that arise, in addition to generating financial stability. It is essential to highlight 3 reasons to save:

- Contingencies, sometimes there are expenses that were not planned, if you have a savings you can immediately respond to this situation, with little or no difficulty.

- Invest, to make money grow.

- Carry out projects, this not only refers to business, but also personal projects such as buying a car, fixing housing, traveling, among others.

\section{Budget}

According to Burbano (2004), a budget is a systematically programmed evaluation of the working conditions and the results to be achieved by a corporation in a certain period of time. In the same way, the budget is a formal quantitative expression of the goals that the company intends to achieve in a while, with the help of established strategies to achieve the proposed. From the conceptual point of view of the Financial Encyclopedia, a budget is the sum of capital that is required to meet a certain amount of expenses that are necessary to undertake a project or business; simply, it can be defined as the predicted amount that determines the cost of realizing any purpose that is had.

Pérez (2009) mentions that the budget is a monetary amount that is calculated and necessary, through the creation of assumptions, for future expenses.

\section{Investment}

Andersen (1999) states that the investment is the placement of capital in a financial procedure or a project with the intention of obtaining a future return. 
The Bank of Mexico expresses that the investment is the use of an amount of money in purchases of goods or durable securities. It is the expense that is consumed to keep in operation or to increase the productive team of an organization. Goods and services produced but not consumed. Sum of excess money that is destined to obtain performance with the help of banking or financial instruments.

\section{Method}

The study carried out was exploratory, descriptive, transversal, causal and using the case study method (Stake, 2007). It was exploratory, since it was sought to investigate and know data of transcendence which propitiated the development of the research topic, descriptive because it was sought to differentiate the knowledge, habits and behaviors that students of fifth grade of the sample have in financial matters chosen, transversal due to the fact that data were collected at a single time and at a certain time and causal because it was sought to know the influence that the different factors used in the investigation had with the chosen sample.

To carry out the present investigation, we worked with a non-probabilistic or intentional sample of type subjects, with 747 students of fifth grade of 34 primary school groups in the city of Navojoa, Sonora; The following criteria were taken into account: they are enrolled students in fifth grade of 34 primary, public and private schools in the city, regardless of the student's gender.

The data were obtained through the design and application of a questionnaire consisting of seven variables, consisting of 35 questions. A quantitative scale was used using the Multiple Response Model (MRP) proposed by Vázquez, Manassero and Acevedo (2005), where each question had three response options constituted through phrases, moving in the appropriate continuum (correct, three points), plausible (slightly correct, two points), and naive (incorrect, one point).

Through the questions contained in the instrument, relevant data on basic financial knowledge, such as savings, budget, inflation, financial institutions, credit, taxes, among other topics, were investigated.
The study was divided into 7 dimensions that evaluated different topics.

\begin{tabular}{|c|c|c|}
\hline Dimensions & $\begin{array}{l}\text { Definition for the } \\
\text { development of the } \\
\text { study }\end{array}$ & Reagents \\
\hline $\begin{array}{l}\text { Saving and } \\
\text { forecasting } \\
\text { habits }\end{array}$ & $\begin{array}{l}\text { Knowledge about } \\
\text { saving, importance of } \\
\text { forecasting, solvency, } \\
\text { as well as prevention. }\end{array}$ & $\begin{array}{r}4,8,20 \text {, } \\
30\end{array}$ \\
\hline Shopping habits & $\begin{array}{l}\text { Individual based } \\
\text { behavior is their logic } \\
\text { when obtaining goods } \\
\text { and contracting } \\
\text { services. }\end{array}$ & $\begin{array}{r}3,17,26, \\
27\end{array}$ \\
\hline $\begin{array}{lr}\text { Use } & \text { and } \\
\text { knowledge } & \text { of } \\
\text { money } & \end{array}$ & $\begin{array}{l}\text { Knowledge about } \\
\text { money, use, origin, } \\
\text { control } \\
\text { administration. }\end{array}$ & $\begin{array}{r}1,12,21, \\
24,35\end{array}$ \\
\hline $\begin{array}{ll}\text { Wealth } & \text { and } \\
\text { abundance } & \end{array}$ & $\begin{array}{l}\text { Management } \\
\text { administration } \\
\text { heritage. }\end{array}$ & $\begin{array}{r}9,14,19, \\
32,33\end{array}$ \\
\hline $\begin{array}{l}\text { Knowledge of } \\
\text { the financial } \\
\text { system }\end{array}$ & $\begin{array}{l}\text { Knowledge of the } \\
\text { financial institutions, } \\
\text { operation and } \\
\text { services they offer. }\end{array}$ & $\begin{array}{r}5,6,7,14 \\
16,18,28, \\
29,31 \\
\end{array}$ \\
\hline $\begin{array}{l}\text { Entrepreneurial } \\
\text { spirit }\end{array}$ & $\begin{array}{l}\text { Innovation and } \\
\text { resource management } \\
\text { for entrepreneurship. }\end{array}$ & $\begin{array}{r}10,11,22, \\
23,34\end{array}$ \\
\hline $\begin{array}{l}\text { Financial } \\
\text { planning }\end{array}$ & $\begin{array}{l}\text { Distribution of } \\
\text { income and expenses } \\
\text { in terms of priority. }\end{array}$ & $2,15,25$ \\
\hline
\end{tabular}

Table 1 Instrument Dimensions

Source: Preparation with instrument data

Authorization was requested in primary schools to work and select the sample under study. Once the permit was obtained, contact was made with the head teachers of each class.

Consecutively, the measuring instrument was applied.

Subsequently, a database was built in the Stadistical Package for the Social Sciences (SPSS) version 23 program, which allowed us to obtain descriptive statistics such as mean and standard deviation. The Cronbach's alpha index of .645 was obtained, which evidenced the validity of the instrument to measure the financial knowledge of the children surveyed (Camacho, 2006; Damián and Huchín, 2010; Nunnally, 1978; Grounlund, 1985; and Rosenthal, in Garcia, 2006). 


\section{Results}

\begin{tabular}{|c|c|c|c|}
\hline \multicolumn{4}{|c|}{ ANOVA } \\
\hline & & $\begin{array}{l}\text { Sum of } \\
\text { squares }\end{array}$ & Sig. \\
\hline \multirow[t]{3}{*}{$\begin{array}{l}\text { Dim Savings and } \\
\text { prevention habits }\end{array}$} & $\begin{array}{l}\text { Between } \\
\text { groups }\end{array}$ & 10.165 & 0.039 \\
\hline & $\begin{array}{l}\text { Within } \\
\text { groups }\end{array}$ & 1871.754 & \\
\hline & Total & 1881.919 & \\
\hline \multirow[t]{3}{*}{$\begin{array}{l}\text { Dim Purchase } \\
\text { Habits }\end{array}$} & $\begin{array}{l}\text { Between } \\
\text { groups }\end{array}$ & 0.716 & 0.561 \\
\hline & $\begin{array}{l}\text { Within } \\
\text { groups }\end{array}$ & 1658.802 & \\
\hline & Total & 1659.518 & \\
\hline \multirow{3}{*}{$\begin{array}{l}\text { Dim Use and } \\
\text { knowledge } \\
\text { money }\end{array}$} & $\begin{array}{l}\text { Between } \\
\text { groups }\end{array}$ & 0.162 & 0.806 \\
\hline & $\begin{array}{l}\text { Within } \\
\text { groups }\end{array}$ & 2106.486 & \\
\hline & Total & 2106.648 & \\
\hline \multirow[t]{3}{*}{$\begin{array}{l}\text { Dim Wealth and } \\
\text { abundance }\end{array}$} & $\begin{array}{l}\text { Between } \\
\text { groups }\end{array}$ & 0.226 & 0.774 \\
\hline & $\begin{array}{l}\text { Within } \\
\text { groups }\end{array}$ & 2145.72 & \\
\hline & Total & 2145.945 & \\
\hline \multirow{3}{*}{$\begin{array}{l}\text { Dim Knowledge } \\
\text { of the financial } \\
\text { system }\end{array}$} & $\begin{array}{l}\text { Between } \\
\text { groups }\end{array}$ & 7.73 & 0.271 \\
\hline & $\begin{array}{l}\text { Within } \\
\text { groups }\end{array}$ & 4985.895 & \\
\hline & Total & 4993.625 & \\
\hline \multirow[t]{3}{*}{$\begin{array}{l}\text { Dim } \\
\text { Entrepreneurship }\end{array}$} & $\begin{array}{l}\text { Between } \\
\text { groups }\end{array}$ & 4.224 & 0.177 \\
\hline & $\begin{array}{l}\text { Within } \\
\text { groups }\end{array}$ & 1812.34 & \\
\hline & Total & 1816.565 & \\
\hline \multirow[t]{3}{*}{$\begin{array}{l}\text { Dim Financial } \\
\text { Planning }\end{array}$} & $\begin{array}{l}\text { Between } \\
\text { groups }\end{array}$ & 33.762 & 0 \\
\hline & $\begin{array}{l}\text { Within } \\
\text { groups }\end{array}$ & 1554.172 & \\
\hline & Total & 1587.934 & \\
\hline
\end{tabular}

Table 2 ANOVA with school type factor Source: Elaboration with own data

As can be seen in Table 2, in the "savings and prevention habits" dimension, there is a value of .039 and in the "financial planning" dimension, 000 being below the approval level, so the type of school which respondents attend if it influences the level of financial education.

It is important to mention that in order for it to be significant and the variable has an influence on the students' financial education, the value must be less than 05 .

\begin{tabular}{|c|c|c|c|}
\hline \multicolumn{4}{|c|}{ ANOVA } \\
\hline & & $\begin{array}{l}\text { Sum of } \\
\text { squares }\end{array}$ & Sig. \\
\hline \multirow[t]{3}{*}{$\begin{array}{l}\text { Dim Savings and } \\
\text { prevention habits }\end{array}$} & $\begin{array}{l}\text { Between } \\
\text { groups }\end{array}$ & 1.91 & 0.672 \\
\hline & $\begin{array}{l}\text { Within } \\
\text { groups }\end{array}$ & 1879.904 & \\
\hline & Total & 1881.814 & \\
\hline \multirow[t]{3}{*}{$\begin{array}{l}\text { Dim Purchase } \\
\text { Habits }\end{array}$} & $\begin{array}{l}\text { Between } \\
\text { groups }\end{array}$ & 5.388 & 0.28 \\
\hline & $\begin{array}{l}\text { Within } \\
\text { groups }\end{array}$ & 1653.509 & \\
\hline & Total & 1658.897 & \\
\hline \multirow{3}{*}{$\begin{array}{l}\text { Dim Use and } \\
\text { knowledge } \\
\text { money }\end{array}$} & $\begin{array}{l}\text { Between } \\
\text { groups }\end{array}$ & 18.187 & 0.034 \\
\hline & $\begin{array}{l}\text { Within } \\
\text { groups }\end{array}$ & 2088.086 & \\
\hline & Total & 2106.273 & \\
\hline \multirow[t]{3}{*}{$\begin{array}{l}\text { Dim Wealth and } \\
\text { abundance }\end{array}$} & $\begin{array}{l}\begin{array}{l}\text { Between } \\
\text { groups }\end{array} \\
\end{array}$ & 11.732 & 0.117 \\
\hline & $\begin{array}{l}\text { Within } \\
\text { groups }\end{array}$ & 2131.636 & \\
\hline & Total & 2143.368 & \\
\hline \multirow{3}{*}{$\begin{array}{l}\text { Dim Knowledge } \\
\text { of the financial } \\
\text { system }\end{array}$} & $\begin{array}{l}\text { Between } \\
\text { groups }\end{array}$ & 24.126 & 0.15 \\
\hline & $\begin{array}{l}\text { Within } \\
\text { groups }\end{array}$ & 4965.155 & \\
\hline & Total & 4989.282 & \\
\hline \multirow[t]{3}{*}{$\begin{array}{l}\text { Dim } \\
\text { Entrepreneurship }\end{array}$} & $\begin{array}{l}\text { Between } \\
\text { groups }\end{array}$ & 3.334 & 0.488 \\
\hline & $\begin{array}{l}\text { Within } \\
\text { groups }\end{array}$ & 1813.028 & \\
\hline & Total & 1816.362 & \\
\hline \multirow[t]{3}{*}{$\begin{array}{l}\text { Dim Financial } \\
\text { Planning }\end{array}$} & $\begin{array}{l}\text { Between } \\
\text { groups }\end{array}$ & 2.536 & 0.535 \\
\hline & $\begin{array}{l}\text { Within } \\
\text { groups }\end{array}$ & 1583.699 & \\
\hline & Total & 1586.234 & \\
\hline
\end{tabular}

Table 3 ANOVA with age factor

In dimension 3 "use and knowledge of money" there is a value of .034 , which means that the age of the respondents does influence money management and therefore if it influences their level of financial education.

The level of financial education for students in the fifth grade of primary schools in the city of Navojoa, Sonora was 1,862, which remains in the naive or incorrect range.

The dimensions in which fifth grade children show a higher level of financial education:

D1 Saving and prevention habits

D3 Use and knowledge of money 
D4 Wealth and abundance

On the contrary, the dimensions in which children show a lower level of financial education:

D4 Wealth and abundance

D5 Knowledge of the Financial System

Of the sample surveyed, 336 children have a savings account, which represents $21.93 \%$, while the rest do not know or have never had a savings account in a formal financial institution.

\section{Acknowledgments}

This article has been supported by PROFAPI which is a program to support researchers at the Sonora Institute of Technology.

\section{Conclusions}

According to UNICEF (2013), it is important that parents instill in their children education and financial culture from an early age, in order to raise awareness of what spending is, that they can measure their savings and develop skills in the face of social problems of this type, so that they can become people with the capacity to change society.

The results obtained in dimension 5 of the present investigation, which is the one that makes reference to the financial system were the lowest, since the students demonstrate not having knowledge about the financial institutions, they do not know the functions of the savings accounts and they have little knowledge of the meaning of interests, this is related to the results of Gómez (2015), who found that students have little savings culture, feel insecure about the use of credit cards and bank loans, all due to ignorance of the information.

Aguilar and Ortiz (2013), found that the students under study of their research had a lowmedium level of financial education, the same level obtained in this research.
Olin (2014) in a study he conducted, found that nine out of ten respondents believe that financial education influences their investment decisions, with this study he stressed the importance of financial education, not only in students but also in people in In general, this is in contrast to the findings of this study which demonstrates a low level of financial education, obtaining a score of 1.86 .

The relationship between the private and public school if it denotes influence on the level of financial education, that is, the type of school if it is significant, however the private primary school shows a level of financial education slightly higher than that of the public school with an average of 1.8 and 1.59 respectively.

The dimension with the lowest score of the public primary school was the knowledge dimension of the financial system, being also the lowest score of the private primary school.

The dimension with a higher score for fifth grade of public primary was the use and knowledge of money, this dimension covers topics on obtaining money, activities to obtain more money, foreign exchange, money production and control of resources, within The reagent with the lowest score was to obtain money, being the same reagent low for private primary school.

In compliance with the specific objective, it was found that the variables in which the students presented a greater domain were habits of saving and prevention as well as use and knowledge of money, while the variables where they showed a lower domain were knowledge of the financial system and planning financial

Finally, the ANOVA model is a statistical method that reveals whether or not there is a relationship between groups. The elaborated ANOVA models show that the sex and occupation of the parents have no influence on the level of financial education, however that the students are enrolled in a public or private school if they have influence on the level. 
In conclusion, the compliance obtained from the financial education project in fifth grade students of the schools of the city of Navojoa, Sonora is shown, according to the results obtained it is possible to conclude the following:

- The objective of the investigation was fulfilled, which sought to know the level of financial education of the students of fifth grade of primary schools of the primary schools of the city of Navojoa, Sonora.

- The specific objective was met, since it sought to know the variables in which the students showed a greater and lesser domain.

- The 7 dimensions managed in the instrument remained in the naive range, demonstrating that there is not a sufficient level of financial education.

- Students show knowledge of the basic financial field.

- Students dominate more easily the use and knowledge of money.

- Students have an area of opportunity in the field of knowledge of the financial system.

- The sex of the respondents is not influential in the level of financial education.

- The occupation of the parents does not influence the level of financial knowledge of the students.

- The type of school does have significance in the level of financial education of the respondents.

It is recommended based on the results obtained, it is important that the sample surveyed be strengthened in the scope of the financial system, in order to inform them of its operation, existing financial institutions, the role of banks, accounts savings, investments, loans, among other elements that make it up, in addition to fortifying their knowledge regarding financial planning.
Likewise, within a project like this, it is always sought that there be continuity of it, which is why it is recommended that it be extended in all the primary schools of the city of Navojoa, Sonora, so that in this way we can have the necessary information to generate training for students in fifth and sixth grade of primary school, applying the necessary strategies and thereby favor the financial education of elementary students, in order to raise awareness and with them to promote their financial future. Together, formulate didactic strategies in order to encourage financial education in the elderly, so that this creates awareness of what financial products and services are as well as their operation.

\section{References}

Andersen, A. (1999). Diccionario de economía y negocios . Madrid: Espasa Calpe, S.A.

ASOBANCARIA. (9 de Octubre de 2017). ASOBANCARIA. Obtenido de ASOBANCARIA:

http://www.asobancaria.com/sabermassermas/h abitos-financieros/

Banco de Ahorro Nacional y Servicios Financieros, S. N. (2005). gob.mx. Obtenido de gob.mx:

https://www.gob.mx/cms/uploads/attachment/fi le/83054/Educaci_n_Financiera.pdf

Burbano, J. (2004). Catedra Financiera. Obtenido de Catedra Financiera: https://catedrafinancierags.files.wordpress.com/ 2015/03/burbano-presupuestos-enfoque-degestic3b3n.pdf

Camacho, J. (2006). Estadística con SPSS para Windows. Madrid: Alfaomega

Dominguez, F. (17 de Julio de 2017). Forbes. Recuperado el 15 de Septiembre de 2018, de Forbes : https://www.forbes.com.mx/mexicomejora-en-educacion-financiera-pero-no-losuficiente/

García, C. (2006). La Medición en las Ciencias Sociales y en la Psicología". En: René Landero (Comp.) Estadística con SPSS y metodología de la investigación. México : Trillas . 
González, C. G. (2015). Universidad Autónoma de San Luis Potosí. Obtenido de Universidad Autónoma de San Luis Potosí: http://ninive.uaslp.mx/jspui/bitstream/i/4158/1/ Tesis\%20Carlos\%20Go\%CC\%81mez\%20Gonz a\%CC\%81lez.pdf

Huidobro, A. (s.f.). gob.mx. Obtenido de http://www.cnsf.gob.mx/Difusion/OtrasPublica ciones/DOCUMENTOS\%20DE\%20TRABAJO $\%$ 20DESCRIPTIVOS/DdT62conimag\%20BV $\% 20 \mathrm{ok} . \mathrm{pdf}$

Nunnally. (1978). Psychometric Theory . New York : McGraw-Hill.

OECD. (Julio de 2005). oecd.org. Obtenido de oecd.org:

https://www.oecd.org/daf/fin/financial-

education/35108560.pdf

Ortiz, J. (7 de Octubre de 2015). Finanzas y proyectos. Obtenido de Finanzas y proyectos: https://finanzasyproyectos.net/importancia-delahorro-joven/

Ortiz, J. (29 de Marzo de 2017). Finanzas y Proyectos. Obtenido de Finanzas y Proyectos: https://finanzasyproyectos.net/razones-

importantes-para-ahorrar/

Pérez, E. R. (2010 ). Fundación Ford. Obtenido de Fundación Ford: http://ford.ciesas.edu.mx/downloads/2do_1_04. pdf

Pérez, J. (2009). Obtenido de https://definicion.de/presupuesto/

Retiro, C. N. (Abril de 2015). gob.mx. Obtenido de gob.mx: https://www.gob.mx/cms/uploads/attachment/fi le/60190/2015_05_importancia_educacion_fina nciera.pdf

Stake, R. E. (2007). Investigación con casos de estudio. Morata.

Sucasaca, J. H. (2016). Repositorio de Tesis . Obtenido de Repositorio de Tesis: http://repositorio.upeu.edu.pe/bitstream/handle/ UPEU/448/Judith_Tesis_bachiller_2016.pdf?se quence $=1 \&$ is Allowed $=\mathrm{y}$
UNICEF. (2013). Unicef. Obtenido de Unicef: https://www.unicef.org/cfs/files/CFS_FinEd_Sp _Web_8_5_13.pdf

Vázquez, A., Manassero, A., \& Acevedo, A. (2005). Análisis cuantitativo de ítems complejos de opción múltiple en ciencia, tecnología y sociedad: Escalamiento de ítems. . Revista Electrónica de Investigación Educativa , 7.

Xirau, M. (24 de Julio de 2018). Forbes. Obtenido de Forbes: http://forbes.es/life/37543/3-habitos-

financieros-deberias-cumplir/

Zunzunegui, F. (Octubre de 2006). Revista de Derecho del Mercado Financiero. Obtenido de Revista de Derecho del Mercado Financiero: https://rdmf.files.wordpress.com/2006/12/quees-la-educacion-financiera.pdf. 